\title{
School Bonding of Adolescent Offenders ${ }^{1}$
}

\author{
Jorge Luiz da Silva \\ Universidade de São Paulo, \\ Ribeirão Preto-SP, Brazil
}

\author{
Ana Raquel Lucato Cianflone \\ Universidade de São Paulo, \\ Ribeirão Preto-SP, Brazil
}

\author{
Marina Rezende Bazon ${ }^{2}$ \\ Universidade de São Paulo, \\ Ribeirão Preto-SP, Brazil
}

\begin{abstract}
Students strongly bonded to the educational institution are more motivated to study and less likely to present behavioral problems and/or juvenile delinquency. This study's objective was to verify the existence of variations in school bonding among different groups of adolescents and identify the most problematic aspects among adolescents in conflict with the law from the perspective of Marc LeBlanc's Social and Personal Control Theory of Deviant Behavior. The 60 adolescents participating in the study responded to the Portuguese version of the School Scale, part of the Measuring Adolescent Social and Personal Adaptation Scale. The results reveal that the level of school bonding differentiated the groups, showing that offenders who dropped out of school obtained the worst indicators of school bonding when considering investment and commitment levels, as well as attachment to teachers.
\end{abstract}

Keywords: adolescent in conflict with the law, schools, school adjustment

\section{Vinculação Escolar de Adolescentes em Conflito com a Lei}

\begin{abstract}
Resumo: Alunos fortemente vinculados à instituição escolar apresentam maior motivação para os estudos e menor probabilidade de manifestação de problemas comportamentais e/ou infracionais. Este estudo objetivou verificar a existência de variações na vinculação escolar em grupos distintos de adolescentes, de modo a localizar os aspectos mais problemáticos àqueles em situação de conflito com a lei, na perspectiva da Teoria da Regulação Social e Pessoal da Conduta Divergente na Adolescência, de Marc LeBlanc. Os 60 adolescentes participantes da pesquisa responderam à versão em português da Escala Escola pertencente ao Measuring Adolescent Social and Personal Adaptation. Os resultados mostram que o nível de vinculação escolar distingue os grupos estudados, denotando-se que os infratores evadidos da escola são os que possuem os piores indicadores de vinculação escolar, considerando-se os níveis de investimento, de empenho escolar e de apego aos professores.
\end{abstract}

Palavras-chave: adolescente em conflito com a lei, escolas, ajustamento escolar

\section{Vinculación Escolar de Adolescentes Infractores de la Ley}

\begin{abstract}
Resumen: Los estudiantes fuertemente vinculados a la institución educativa tienen más motivación para los estudios y presentan menos probabilidad problemas comportamentales y delictivos. Este estudio tuvo como objetivo verificar la existencia de variaciones en la vinculación con la escuela en diferentes grupos de adolescentes con el fin de localizar los aspectos más problemáticos para aquellos en conflicto con la ley, en vista de la Teoría de la Regulación Social y Personal de Conducta Deviante en la Adolescencia, de Marc LeBlanc. Los 60 participantes respondieron a la versión en portugués de la Escala Escuela perteneciente al Measuring Adolescent Social and Personal Adaptation. Los resultados muestran que el nivel de vinculación escolar diferencia a los grupos: los infractores de la ley en deserción escolar son los que presentan los peores indicadores de participación en las actividades académicas, en compromiso con la escuela y en apego a los maestros.
\end{abstract}

Palabras clave: adolescente en conflicto con la ley, escuelas, adaptación escolar

In our society, school is one of the most important environments influencing development during adolescence since experience at school at this stage of life becomes a

\footnotetext{
${ }^{1}$ This paper was derived from the master's thesis of the primary author under the supervision of the third author, defended in 2013 within the Graduate Program in Psychology at Faculdade de Filosofia, Ciências e Letras de Ribeirão Preto, Universidade de São Paulo (FFCLRP/USP).

Support: São Paulo Research Foundation (FAPESP - Process No. 2013/04634-9)

${ }^{2}$ Correspondence address:

Marina Rezende Bazon. Grupo de Estudos e Pesquisa em Desenvolvimento e Intervenção Psicossocial (GEPDIP), Departamento de Psicologia da Faculdade de Filosofia, Ciências e Letras de Ribeirão Preto - USP. Av. Bandeirantes, 3900. Monte Alegre. CEP 14040-901. Ribeirão Preto-SP, Brazil. E-mail: mbazon@ffclrp.usp.br
}

variable that leads to turning points in terms of individual trajectory (Moshman, 2005). From this perspective, there has been an intensification of discussions concerning the structural aspects of education, especially concerning high school and its social function since Constitutional Amendment No. 59/2009 was enacted. It changed sections I and VII of Article 208 of the Federal Constitution ensuring "free and mandatory basic education to children from four to 17 years of age $[. .]$.$" . The increased rate of failure in the last$ year of middle school and corresponding drop in the number of students (Lima, 2011) can lead to premature termination of adolescents' school trajectory (Lima \& Gomes, 2013). The analysis performed by Castro (2008) shows that all problems regarding the quality of elementary and middle schools 
accumulate and have repercussions for high school, the model of which has no precedent in the world. There are no alternative paths at this level of schooling in Brazil; that is, there are no schools with different profiles (European model) nor is there the possibility to choose different alternatives within the same school (American model). The only exceptions are the technical schools, which strictly speaking, consist of the conventional curriculum with the addition of a technical curriculum (Castro, 2008). In this context, the risk of dropping out during high school reaches alarming proportions (Neri, 2009).

In addition to the classical form of dropping out, there are currently new forms of exclusion, that is, there is a range of students who remain in the system but experience a decline, a "delayed elimination" (Freitas, 2007), gradually and progressively detaching from school despite being formally enrolled. A fragile bond with the school is generally associated with difficult adjustment to the school environment, a problem of modern society, which in the individual sphere, leads to a significant increase of deviant behavior, such as the consumption of illegal substances, violence, and school dropout (Bryan et al., 2012; Estevam, Coutinho, \& Araújo, 2009; Ford \& Schroeder, 2011).

The concept of bonding in the human and social sciences refers to the idea of a mutual effort among the members of a group to reciprocally move toward a common goal or objective. In psychology, its use in research and theorizing is related to attempts to overcome the classical consideration of its object in terms of individual phenomena, and enforce the assertion that humans are inherently social beings and are constituted as individuals in the context of social exchanges and experiences (Carvalho, Bastos, Rabinovich, \& Sampaio, 2006). In this sense, school bonding is conceived as a multidimensional phenomenon that encompasses behavioral, affective and cognitive factors activated in interactions and in the school environment, depending on how bonding of students to education in general, to rules, and to the values defended by the school, as well as to those who compose the school team and peers, is manifested.

In summary, school bonding and adjustment develop together and feed each other based on the interaction of students with and within the school context in response to environmental variables, a requirement for good performance and the prevention of deviant behavior within the school and outside it (Bryan et al., 2012). Weak bonding, in turn, favors deviant behavior within the school, which in turn, requires institutional disciplinary actions leading to even greater student disengagement and poorer student performance. These conditions may lead to dropping out, consequently harming adolescents who are then unable to enjoy the benefits education can offer (Feijó \& Assis, 2004).

It is known that adolescents in conflict with the law have a number of school problems, among which is poor bonding. These individuals are characterized by having weak attachment to their teachers and the school staff, low educational aspirations, and low investment in school activities when compared to adolescents from public schools who are not in conflict with the law (Oliveira, 2002; Zappe \& Ramos, 2010). Adolescent offenders in general present poor academic performance marked by failure and an important lag between age and school year, while dropout rates among this group are considerably higher (Toledo \& Bazon, 2005). Despite these difficulties, psychosocial support provided to adolescents in conflict with the law should necessarily involve school (re)integration and/ or career and technical education and training (Law No. 12.594, 2012). Hence, the study of variables and mechanisms involved in the school bonding process conducted with adolescents can help in understanding the problem and the implementation of more specific interventions designed to improve the experience of this segment of the population at school (Maddox \& Prinz, 2003).

For that, this study utilizes the theoretical model pertaining to the Theory of Social and Personal Control of Deviant Behavior during Adolescence developed by Le Blanc (1997) and Le Blanc, Ouimet and Szabo (2003). In this framework, school bonding is seen as a multidimensional concept and involves the following variables: Investment, Commitment and Attachment to Teachers. Investment corresponds to time that is dedicated to studies together with a feeling of being competent or not, coupled with the conception of doing one's best at school and motivation to participate in extracurricular activities. The time spent with school-related activities - attendance and homework - in this model is directly related to students' performance (grades) and also to the level of Attachment to teachers (Le Blanc, 1997). Commitment, understood as one being engaged in education, refers to an obligation, more or less internalized by adolescents, to attend school and study. In the studies conducted by Le Blanc et al. (2003), Commitment is negatively related to school dropout and depends on the perception of having the competence to face school demands. Perceiving oneself as being competent prompts a positive attitude toward school and education, essential to determining expectations regarding the duration of studies. Commitment is linked to the level of importance that is attributed to school success and educational aspirations. Attachment, in turn, refers to a positive affection that may or may not pervade the relationship between student and professor. It is based on communication with teachers regarding school experience, in the affective identification with teachers and assurance in regard to having support for school subjects whenever necessary. Communication is key in this theoretical scheme because it is the route through which a perception that help is available is built upon, while it also supports affective identification of the student with the teacher (Le Blanc et al., 2003). Additionally, when attachment to teachers is strong, it reinforces Commitment, which in turn, favors one's perception of school rules and standards as being legitimate (Le Blanc, 1997).

Problems in the components of school bonding encourage gradual disengagement from school on the part of students, which in combination with other personal, social and contextual variables, supports the emergence of deviant behavior. Such behavior is in fact a way to respond to difficulties and failures (Janosz \& Le Blanc, 1999). Note that the theoretical model proposed by Le Blanc et al. (2003) is integrative and has a systemic nature, assuming a dynamic interaction with a feedback effect among variables of a personal, familial and social/community nature. Variables relating to systems other than the school system permeate and influence school bonding, as well as the relationship between this variable and delinquent behavior. In this study, however, we focus on behavior control promoted by the school and within school.

Given the previous discussion, this study's objective was to verify the existence of variations in school bonding 
in distinct groups of adolescents in order to identify the most problematic aspects among those in situations of conflict with the law from the perspective of the Theory of Social and Personal Control of Deviant Behavior during Adolescence considering the variables proposed in the model and its indicators: School Investment - (a) time spent with school activities and (b) extracurricular activities; School Commitment - (c) an adolescent's perception concerning his/her academic competence, (d) attitude toward school/ education, (e) importance attributed to school success, and (f) educational aspirations; Attachment to Teachers - (g) affective identification with teachers, and (h) perception that help is available.

\section{Method}

\section{Participants}

A total of 60 adolescents aged between 14 and 18 years old $(M=16.6$ years) were divided into four groups composed of 15 participants: adolescent offenders who dropped out of school (O-Drop); adolescent offender students (O-S); adolescent non-offenders who dropped out of school (NODrop); adolescent non-offender students (NO-S). The average time since adolescents had dropped out of school was 2.07 years for those in conflict with the law (O-Drop) and 1.93 years for those with no offender behavior (NO-Drop). An age/ school year gap was observed in the four groups, while the averages were significantly different: adolescent offenders who dropped out of school - 4.93; offender students - 2.87; non-offenders who dropped out of school - 3.93; and nonoffender students - 2.00 .

The study was conducted in the city of Ribeirão Preto, SP, Brazil and all the adolescent offenders (O-Drop and O-S) were recruited in the city programs that implement socio-educational measures outside prisons, while non-offender students (NOS) were recruited from public schools. To compose the group of non-offender adolescents who dropped out of school (NODrop), we asked the city's guardian council for a list of names and addresses of dropout students. This study was consisted of an unintentional, non-probabilistic convenience sample.

All the adolescents reported being single and having no children. Most $(80.0 \%)$ of the individuals in the four groups belonged to families classified by the Brazil Socioeconomic Classification Criteria as Class $\mathrm{C}$, which corresponds to families with incomes ranging between U\$ 345,00 and U\$ 1490,$00 ; 54.2 \%$ of Brazilian families belong to class C (Associação Brasileira de Empresas de Pesquisa [ABEP], 2010). Eleven adolescents reported having a job: seven offenders (five in the O-Drop group and two in the O-S) and four non-offenders (one in the NO-Drop group and three in the NO-S group). The occupations reported by those in conflict with the law included: car wash assistant; LAN house attendant; mason apprentice and security guard; the remaining adolescents reported: grocery store packer; mason apprentice, and mechanic's helper. The comparative analysis showed no significant differences among the four groups in this aspect $(p \geq .58)$.

In regard to infractions committed by adolescent offenders (O-Drop and O-S), most report drug trafficking $(65.1 \%)$, followed by theft $(23.4 \%)$, robbery $(6.8 \%)$, threatening (3.4\%) and aggression (1.7\%). These findings differ slightly from the pattern observed in the state of São Paulo (SEDH, 2011), where $43.1 \%$ of the apprehended adolescents report theft and $39.6 \%$ report drug-trafficking, while the remaining $17.3 \%$ is distributed among other types of infractions (robbery, armed robbery, receiving stolen goods, and especially threatening).

\section{Instrument}

The Portuguese version of the School Scale from the Measuring Adolescent Social and Personal Adaptation MASPAQ (Le Blanc et al., 2003) was used. It is based on the Theory of Social and Personal Control of Behavior; the internal consistency alphas for its subscales range from .64 and .91. The scale is composed of 68 questions, which require answers to be checked on a Likert scale (always, often, sometimes, never) in most instances. The instrument was semantically adapted to Portuguese with the author's consent using procedures indicated in the literature (Pasquali, 1998). It assesses the individuals' perceptions of what conditions encourage or discourage school bonding - Investment, Commitment and Attachment to Teachers - through questions developed around indicators of these conditions. The following are examples of questions related to the constructs: Investment - "How many hours do (did) you usually take to do your homework, tasks and research at school and at home?"; Commitment - "To what extent is (was) it important to you to obtain good grades?"; Attachment "To what extent is (was) it easy at your school to get help from professors when students have (had) difficulty with subjects?".

Hence, the instrument seeks to obtain information from adolescents concerning their relationship with the school, assuming that the most important information to understand how these individuals interact with the school are their perceptions concerning the school. Even though this source of information is likely to distort reality, be subject to memory failures, personal interpretations and confabulations, it is the most basic and relevant material available when adolescents are taken into account (Le Blanc, 2001a).

\section{Procedure}

Data collection. The School Scale was applied as a structured interview, as this is the modality indicated when the objective is to homogenize the quality of data collected, that is, to reduce differences given varied reading skill levels within the group. For this reason, the researcher read the questions and alternatives for answers when that was the case, and took note of the adolescents' responses. Each interview took 30 minutes on average. Data was collected in the institutions where the adolescents were recruited and in the adolescents' homes in the case of the NO-Drop group.

Data analysis. The responses provided to the Scale were included in the MASPAQ's computer program - Version 2.0 for Windows (Le Blanc, 2001b), which provided the raw scores for each participant. Afterwards, data were entered into a spreadsheet in the Excel program for statistical treatment. 
An analysis was initially performed basically to synthesize a series of values of the same nature, organizing and describing them through tables presenting descriptive measures. Next, the groups were compared using the Kruskall-Wallis test and the Dunn posttest. The analyses were performed using R 2.14 (R Development Core Team, 2011) and a significance level of .05 was used in all the tests.

\section{Ethical Considerations}

The study project was submitted to and approved by the Institutional Review Board at the Faculdade de Filosofia,
Ciências e Letras de Ribeirão Preto, Universidade de São Paulo (FFCLRP-USP), according to Process CEP No. 579/2011 2011.1.1321.59.8. The parents or legal guardians voluntarily signed free and informed consents so they received all information necessary for decision-making concerning the study.

\section{Results}

The results concerning the eight dimensions of school bonding are summarized in Tables 1 and 2, which present descriptive measures and statistical differences found in the comparison of the four groups.

Table 1

Results of Comparisons Between Groups Relating to Investment and Commitment

\begin{tabular}{|c|c|c|c|c|c|c|c|}
\hline & \multirow{2}{*}{$M$} & \multirow{2}{*}{$S D$} & \multirow{2}{*}{$M d n$} & \multirow{2}{*}{$p$} & \multicolumn{3}{|c|}{ Difference between groups* } \\
\hline & & & & & O-Drop & $\mathrm{O}-\mathrm{S}$ & NO-Drop \\
\hline \multicolumn{8}{|l|}{ Investment } \\
\hline Shool activities & & & & .001 & & & \\
\hline O-Drop & 0.64 & 1.34 & 0.00 & & & & \\
\hline $\mathrm{O}-\mathrm{S}$ & 4.27 & 1.67 & 4.00 & & $\mathrm{~T}$ & & \\
\hline NO-Drop & 2.47 & 2.23 & 3.00 & & $\mathrm{~F}$ & $\mathrm{~F}$ & \\
\hline $\mathrm{NO}-\mathrm{S}$ & 4.44 & 1.97 & 4.00 & & $\mathrm{~T}$ & $\mathrm{~F}$ & $\mathrm{~F}$ \\
\hline Extracurricular activities & & & & .001 & & & \\
\hline O-Drop & 0.86 & 1.75 & 0.00 & & & & \\
\hline $\mathrm{O}-\mathrm{S}$ & 2.73 & 1.53 & 2.00 & & $\mathrm{~T}$ & & \\
\hline NO-Drop & 1.40 & 1.40 & 2.00 & & $\mathrm{~F}$ & $\mathrm{~F}$ & \\
\hline NO-S & 2.44 & 1.15 & 2.00 & & $\mathrm{~T}$ & $\mathrm{~F}$ & $\mathrm{~F}$ \\
\hline \multicolumn{8}{|l|}{ Commitment to education } \\
\hline Attitude toward school & & & & .001 & & & \\
\hline O-Drop & 0.57 & 1.22 & 0.00 & & & & \\
\hline $\mathrm{O}-\mathrm{S}$ & 3.47 & 1.51 & 4.00 & & $\mathrm{~T}$ & & \\
\hline NO-Drop & 2.27 & 1.98 & 4.00 & & $\mathrm{~F}$ & $\mathrm{~F}$ & \\
\hline NO-S & 3.13 & 1.54 & 4.00 & & $\mathrm{~T}$ & $\mathrm{~F}$ & $\mathrm{~F}$ \\
\hline $\begin{array}{l}\text { Perception concerning } \\
\text { academic competence }\end{array}$ & & & & .001 & & & \\
\hline O-Drop & 0.64 & 1.50 & 0.00 & & & & \\
\hline $\mathrm{O}-\mathrm{S}$ & 2.60 & 0.99 & 3.00 & & $\mathrm{~T}$ & & \\
\hline NO-Drop & 1.53 & 1.36 & 2.00 & & $\mathrm{~F}$ & $\mathrm{~F}$ & \\
\hline NO-S & 3.06 & 1.12 & 3.00 & & $\mathrm{~T}$ & $\mathrm{~F}$ & $\mathrm{~F}$ \\
\hline $\begin{array}{l}\text { Importance of achieving } \\
\text { school success }\end{array}$ & & & & .001 & & & \\
\hline O-Drop & 0.50 & 1.09 & 0.00 & & & & \\
\hline $\mathrm{O}-\mathrm{S}$ & 3.20 & 1.08 & 3.00 & & $\mathrm{~T}$ & & \\
\hline NO-Drop & 2.13 & 1.85 & 3.00 & & $\mathrm{~F}$ & $\mathrm{~F}$ & \\
\hline NO-S & 3.13 & 1.02 & 3.00 & & $\mathrm{~T}$ & $\mathrm{~F}$ & $\mathrm{~F}$ \\
\hline Educational aspirations & & & & .001 & & & \\
\hline O-Drop & 0.36 & 0.84 & 0.00 & & & & \\
\hline $\mathrm{O}-\mathrm{S}$ & 3.00 & 1.13 & 3.00 & & $\mathrm{~T}$ & & \\
\hline NO-Drop & 2.13 & 1.85 & 3.00 & & $\mathrm{~F}$ & $\mathrm{~F}$ & \\
\hline NO-S & 3.25 & 1.06 & 3.50 & & $\mathrm{~T}$ & $\mathrm{~F}$ & $\mathrm{~F}$ \\
\hline
\end{tabular}

Note. O-Drop $=$ adolescent offenders who dropped out of school, O-S $=$ adolescent offender students, NO-Drop $=$ adolescent non-offenders who dropped out of school, NO-S = adolescent non-offender students, $\mathrm{F}=$ false, $\mathrm{T}=$ true.

$* p \leq .05$. 
With regard to Investment (Table 1), the offenders who dropped out of school (O-Drop) significantly differed from their counterparts (NO-S) in regard to time spent with School Tasks and School Support Activities. In summary, offender students spent more time in activities having school content than did those who dropped out of school at the time they used to attend school. Therefore, offender students made their best effort to meet the school's expectations. They also more frequently participated in extracurricular activities (cultural activities and sports) as opposed to the offenders who dropped out of school, during the time they attended school. A significant difference was also found between the offenders who dropped out of school (O-Drop) and non-offender students (NO-S). The offenders presented much lower levels of Investment for both types of activities, school and extracurricular activities. Note that among the four groups, the non-offender students (NO-S) presented the highest level of investment in school activities, while offender students (O-S) stood out from the remaining groups for getting more involved in extracurricular activities, most of which athletic activities.

Significant differences were found specifically in regard to Commitment (Table 1) in the comparison between
O-Drop and O-S groups and between O-Drop and NO-S. The two groups of students were more committed to school in comparison to the adolescents who dropped out of school. The O-S group scored higher in Importance of Achieving School Success and in Attitude Toward School, showing they recognize the importance of education.

In regard to the third and last component of school bonding, Attachment to Teachers (Table 2), the results are similar to the previous components. Significant differences were found between the O-Drop and O-S groups and between O-Drop and NO-S. Offender students (NO-S) presented greater Affective Identification with Teachers in comparison to the other groups. On the other hand, the perceptions of offender students (O-S) regarding the Availability of Help was more positive. Conversely, the lowest levels of Attachment to Teachers were observed in the group composed of offenders who dropped out of school (O-Drop). The average level of attachment of the non-offender adolescents who dropped out of school (NO-Drop) was below that of the groups composed of students, though almost four times higher the average presented by the offender students who dropped out of school (O-Drop).

Table 2

Results of Comparisons Between Groups Relating to Attachment to Teachers

\begin{tabular}{|c|c|c|c|c|c|c|c|}
\hline \multirow{2}{*}{ Attachment to teachers } & \multirow{2}{*}{$M$} & \multirow{2}{*}{$S D$} & \multirow{2}{*}{$M d n$} & \multirow{2}{*}{$p$} & \multicolumn{3}{|c|}{ Difference between groups* } \\
\hline & & & & & O-Drop & $\mathrm{O}-\mathrm{S}$ & NO-Drop \\
\hline Affective identification with teachers & & & & .001 & & & \\
\hline O-Drop & 0.29 & 0.61 & 0.00 & & & & \\
\hline $\mathrm{O}-\mathrm{S}$ & 2.20 & 1.01 & 2.00 & & $\mathrm{~T}$ & & \\
\hline NO-Drop & 1.67 & 1.54 & 2.00 & & $\mathrm{~F}$ & $\mathrm{~F}$ & \\
\hline NO-S & 2.56 & 0.96 & 3.00 & & $\mathrm{~T}$ & $\mathrm{~F}$ & $\mathrm{~F}$ \\
\hline Perception that help is available & & & & .001 & & & \\
\hline O-Drop & 0.43 & 1.09 & 0.00 & & & & \\
\hline $\mathrm{O}-\mathrm{S}$ & 3.13 & 1.30 & 4.00 & & $\mathrm{~T}$ & & \\
\hline NO-Drop & 1.80 & 1.61 & 2.00 & & $\mathrm{~F}$ & $\mathrm{~F}$ & \\
\hline $\mathrm{NO}-\mathrm{S}$ & 2.69 & 1.14 & 3.00 & & $\mathrm{~T}$ & $\mathrm{~F}$ & $\mathrm{~F}$ \\
\hline
\end{tabular}

Note. O-Drop $=$ adolescent offenders who dropped out of school, O-S = adolescent offender students, NO-Drop = adolescent non-offenders who dropped out of school, NO-S = adolescent non-offender students, $\mathrm{F}=$ false, $\mathrm{T}=$ true.

$* p \leq .05$.

\section{Discussion}

First, we discuss the results obtained in the Investment component regarding the groups that presented the highest scores concerning time spent with School Activities were the groups of students (O-S and NO-S). Considering the systemic nature of the theoretical model used, which implies circular causal reasoning: the fact they continue studying encourages them to invest in school activities and is also a result of such investment, which seems essential to develop a commitment to studies. This information is especially relevant for the offenders because such investment works as a protective factor against continued involvement with crime, possibly preventing dropout and recurrence of violations (Bazon, Silva, \& Ferrari, 2013; Chui \& Chan, 2012). In turn, dropping out of school among certain adolescents may intensify contact with other individuals in the same situation and participation in routine activities that take place without the supervision of adults. When these adolescents are exposed to other specific risk variables, associated with delinquency engaging, dropout may become an important milestone for either starting criminal behavior or aggravating it (Bazon et al., 2013; Hirschfield, 2009).

Offenders who dropped out of school exhibited the lowest levels of investment in school content in comparison to the other groups, which seems to indicate they were 
already quite disengaged from school at the time they still attended it. These individuals represent, to a great extent, many adolescents in conflict with the law. According to a national survey performed by the National Council of Justice (2012), 57\% of the adolescents in detention institutions had dropped out of school before being apprehended (Toledo \& Bazon, 2005). The theoretical framework used shows that low investment drastically reduces school bonding and often stems from poor academic performance but, at the same time, leads to poor performance for not working on school tasks (Ford \& Schroeder, 2011; Le Blanc et al., 2003; Zappe $\&$ Ramos, 2010). This aspect represents an important point to receive focus in the work of school reintegration of adolescent offenders who dropped out of school in regard to monitoring these students and implementing socio-educational measures, as recommended by law (Law No. 12.594, 2012). As stated by Janosz and Le Blanc (1999), ensuring a slot at school is not enough for adolescents experiencing processes of disengagement and dropout associated with criminal conduct, it is also necessary to create conditions for their level of investment and commitment with school activities to be comparable to that of other students in order to contribute to the development of a sense of belonging to a specific cultural group, according to the propositions of Bruner (2001).

It is worth noting that the adolescents in conflict with the law who were attending school (O-S) presented average levels of investment in school activities, almost equivalent to the levels exhibited by non-offender students (NOS), presenting even greater investment in extracurricular activities than the other groups. According to the information provided, these activities were essentially athletic activities with a pro-social nature. Participation in this type of activity in pro-social contexts, especially on the school premises may be an additional protection and encourage school bonding among these individuals (Kobayashi \& Zane, 2010). Contrary to common sense, however, investment in athletic activities may also, depending on the circumstances, be a route to involvement in deviant activities. Miller, Melnick, Barnes, Sabo and Farrell (2007) state that involvement in this type of activity with peers who exhibit anti-social behavior, without intense supervision of pro-social adults, imposes the risk of adolescents adopting similar behavior, as they have a need to belong to the group; i.e., they may assume a deviant identity. Additionally, the characteristic violent nature of some sports may also model behavior expandable to other situations or social contexts. Hence, the context in which extra-school activities are performed and the quality of social interactions they promote are more important than the content of the activity itself and how intense the involvement of students is.

These considerations may explain the results found for the group of offenders who dropped out of school (O-Drop) indicating significant investment in extra school activities of an athletic nature at the time they still attended school in comparison to their investment on academic activities. Therefore, the investment of this group on extra school activities (perhaps at the expense of investment on academic activities) even if of athletic nature, apparently does not protect them from disengagement from school and becoming involved with activities that violate the law. Perhaps, because of the context in which these activities took place, they contributed to drive these adolescents away from the school environment leading to a criminal behavior.

In regard to Commitment, it should be recalled that it represents a positive attitude toward school and is based on the student's perception concerning his/her abilities to meet academic demands and take studies further (Le Blanc et al., 2003), we highlight the fact that both groups of students obtained higher general averages. It is interesting to note that offender students showed a high rate of having a positive attitude toward school and acknowledged the importance of education. Education is very important for young individuals to advance in their careers and social lives (Feijó \& Assis, 2004), but if school and professional success is uncertain, educational aspirations are reduced and adolescents may have little motivation to postpone immediate gratification to obtain benefits in the future, which in turn paves the way to school disengagement and withdrawal from studies (Zappe \& Ramos, 2010).

At this point, many adolescents glimpse the possibility of entering the job market but, for some, this may not become a concrete alternative due to poor educational level (Sartório \& Rosa, 2010). In this sense, note that few adolescents from the studied sample reported having a job $(n=11)$; no statistical significance was found among the groups in regard to this aspect. In any case, data provided from these few adolescents show that when adolescents are able to enter the job market, the positions they occupy do not require a high level of qualification and seem not to be very suitable for promoting the integral development of young people, if not absolutely inappropriate to this age range (such as the "security guard" for instance). In this scenario, the involvement of these individuals in deviant and criminal activities is favored by exposure to other risk factors.

Hence, the perception that one may succeed academically is a significant protective factor against school dropout and may contribute to one's commitment to overcome the pursuit of instant gratification, whatever it may be. The Theory of Control states that adolescents who are more committed to school are less likely to present disciplinary or criminal behavior to the extent they try to meet the demands and expectations inherent to the educational context (Le Blanc et al., 2003). Therefore, within this theoretical framework, lower Commitment levels, in addition to affecting Investment, are also related to the intensity of disciplinary problems that manifest within the school context and, consequently, the amount of control, which often consists of punitive measures, implemented by the school authorities, which in turn, aggravate disengagement and make dropping out more likely. This study's results corroborate this relationship to the extent that lower levels of Commitment were presented by both groups of adolescents who dropped out of schools.

In regard to Attachment to Teachers, the group of offenders who dropped out of school presented the lowest average among the four groups. At the same time, the group of offender students presented the highest levels concerning Perception of Help Available, while non-offender students 
stood out in regard to Affective Identification to Teachers. Because quality interpersonal relationships between students and professors are strongly associated with school performance and the absence of disciplinary and ruleviolating behaviors (Liljeberg, Eklund, Fritz, \& Klinteberg, 2011), this result indicates that this aspect certainly represents a protection for both groups of students. In the School Control model, according to the Theory of Social and Personal Control, Attachment to Teachers is important because it represents a feeling that help, within the academic plan, is available whenever necessary (Le Blanc et al., 2003). Students see support received from teachers in times of difficulty as an indicator of interest, respect and appreciation. Such a perception, in turn, reinforces communication characterized by dialogue between teachers and students, not only in regard to school content, but also in regard to advice, compliments and encouragement on the part of teachers. This relational proximity based on reciprocal respect, enables school bonding by increasing Investment and Commitment and reducing the need to apply disciplinary measures, because adherence to school rules transmitted by the teachers takes a natural course (Le Blanc, 1997).

Therefore, the quality of the relationships between teachers and students requires special attention in any program of school reintegration, especially if the recipients are adolescents in conflict with the law, since these individuals, according to the literature, often present a history of problematic relationships with teachers, while at the same time they lack significant authority figures with whom they can identify and establish stable relationships (Bazon et al., 2013; Costa \& Assis, 2006). Because learning is a relational process that implies human beings and affection, it is the role of schools to strive for the quality of human contact they enable for students, with adults and among peers (Jost, 2010; Le Blanc, 1994).

These results and the literature indicate that stronger school bonding supported by attachment to teachers has the potential to reduce the risk of adolescents becoming involved in deviant behavior, including violations of rules and laws, not only because of the negative impact this behavior may have on their academic aspirations, but also due to the fear of jeopardizing significant social relationships (Ford \& Schroeder, 2011). From a prospective point of view, solid and quality interpersonal relationships increase the chances of school success, which in turn leads to higher educational goals. Therefore, in addition to focusing on content-learning, schools need to create conditions conducive to healthy social relationships (Costa \& Assis, 2006), especially those involving students and the teacher figure to the extent these relationships enable communication, a perception that help is available, and affective identification, all of which favor human development and reinforce learning, academic performance and school bonding.

According to the Control Theory, poor communication between teacher and student works against these positive processes, favoring poor or no attachment coupled with educational failure and encourages less commitment to education and gradual disengagement from school. As a consequence, motivation to pursue immediate gratification, through taking part in risk activities, possibly involving legal violations, increases (Le Blanc, 1994; Le Blanc et al., 2003). Thus, we highlight the point that the poor Attachment to Teachers experienced by the adolescents from the O-Drop group indicate they face significant difficulties in social interactions with authority figures within the school, figures who otherwise could be an attachment figure and model of pro-social behavior. This lack of attachment to these authority figures certainly makes these adolescents more vulnerable to processes of identification with other models from within their communities, some of which are anti-social models. The decision to drop out of school, fostered by relationship difficulties in this sphere, also increases the likelihood that adolescents will occupy their idle time - outside school - with deviant activities, away from supervision from conventional adults.

Because the adolescents from the O-Drop group presented more negative indices concerning school bonding, the assessment of these individuals shows that, in addition to objective negative indicators related to a long period out of school and great age-school year gap, they are in situations that require resources to motivate them to resume their studies. In the absence of programs specifically designed for this purpose and that take into account the various aspects of a psychosocial nature that underlie the process of school bonding. Due to the impossibility of proper inclusion in the job market as an alternative and all the difficulties already mentioned, these adolescents are left to fend for themselves because of the conditions in which they live and which will affect the course of their development.

In summary, the results indicate that the non-offender students (NO-S) are those with the best levels of school bonding, in contrast with the offenders who dropped out of school with the worst levels of school bonding, which shows the importance of this variable to the continuity of studies during adolescence and its potential protective factor against the involvement of these individuals with deviant behavior and legal violations. Even though offender students (O-S) present a history of violations, they present good levels of school bonding, indicating that school attendance, when there is Investment, Commitment and Attachment, enables stronger school bonding, and, at the same time, results in it.

Even though assessing the school bonding of adolescents who passed through the Justice System is a complex task, it shows an important dimension of the work that has to be done over the course of the socio-educational monitoring of these individuals. This assessment enables the identification of psychosocial aspects that need to be addressed in order to create conditions conducive to effective school reintegration, with the objective to positively influence these adolescents' development. The inappropriate implementation of school integration for these adolescents in conflict with the law may lead to further failure, compounding their vulnerability, since new negative experiences generate stress, discouragement, and lead to a feeling of exclusion. In this sense, the establishment of a school team intended to deal with the main factors that affect school bonding is an additional element that needs to be considered.

In regard to this study's limitations, it is important to 
note the reduced number of participants. We should also note that only "official violations" were taken into account; that is, some of the participants had already passed through the criminal justice system, while others had not. This constitutes bias because it is known that there are adolescents who passed through the justice system but their violations may be occasional and can even be seen as part of a process that is considered normal from a statistical perspective, while others may not have officially passed through the system but still present concealed but intensive deviant activity. Despite the challenge that exists in recruiting participants in this field, future studies with similar objectives should make an effort to address larger and more diversified samples based on more sophisticated sampling methods.

Another limitation to be noted is that the results obtained in this study were exclusively based on data collected through the application of a self-report scale, the weaknesses of which were already mentioned in the method section (instrument). Other studies can improve on this aspect by performing investigations based on other methodologies, perhaps observational studies, with students at risk of dropping out or who have recently dropped out. Nonetheless, it is important to stress that the results obtained with this instrument are valid and consistent with the hypotheses of the theory on which it is based. Additionally, it is worth noting that these results were produced with answers provided to questions related to the indicators of the constructs Investment, Commitment, and Attachment and did not directly or explicitly address or question the participants, a condition that avoids potential biases, such as socially expected answers, or stereotypical and/or conventional answers.

Finally, it is important to mention that aspects related to school characteristics, such as climate, curriculum, teaching strategies, etc., are outside the scope of the assessment intended for the instrument used. Similarly, certain contextual factors such as disorganization in the school environment and especially the presence of violence among peers, are aspects that cannot be disregarded in the assessment of inclusion processes and school reintegration, since these situations significantly harm all those in the institution. Hence, other studies can address a range of relevant variables implicated in the process of school bonding and disengagement from school during adolescence.

\section{References}

Associação Brasileira de Empresas de Pesquisa. (2010). Critério de classificação econômica [Criteria for economic classification]. Retrieved from http://www. abep.org/criterioBrasil.aspx

Bazon, M. R., Silva, J. L., \& Ferrari, R. M. (2013). Trajetórias escolares de adolescentes em conflito com a lei [School trajectories of adolescents in conflict with the law]. Educação em Revista, 29(2), 175-199. doi:10.1590/ S0102-46982013000200008

Carvalho, A. M. A., Bastos, A. C. S. B., Rabinovich, E. P., \& Sampaio, S. M. R. (2006). Vínculos e redes sociais em contextos familiares e institucionais: Uma reflexão conceitual [Bonds and social networks in family and institutional contexts: A conceptual reflection]. Psicologia em Estudo, 11(3), 589-598. doi:10.1590/ S1413-73722006000300015

Castro, C. M. (2008). O ensino médio: Órfão de ideias, herdeiro de equívocos [High School: Orphan of ideas, heir of misunderstandings]. Ensaio: Avaliação e Políticas Públicas em Educação, 16(58), 113-124. doi:10.1590/ S0104-40362008000100008

Conselho Nacional de Justiça. (2012). Panorama nacional: A execução das medidas socioeducativas de internação [National focus: The implementation of the socioeducative measure of internment]. Retrieved from http://www.cnj.jus.br/images/pesquisas-judiciarias/ Publicacoes/panorama_nacional_doj_web.pdf

Bruner, J. S. (2001). Cultura, mente e educação [Culture, mind and education]. In A cultura da educação [The culture of education] (M. A. G. Domingues, Trans., pp. 89-99). Porto Alegre, RS: Artmed.

Bryan, J., Moore-Thomas, C., Gaenzle, S., Kim, J., Lin, C.H., \& Na, G. (2012). The effects of school bonding on high school seniors' academic achievement. Journal of Counseling \& Development, 90(4), 467-480. doi:10.1002/ j.1556-6676.2012.00058.x

Chui, W. H., \& Chan, H. C. O. (2012). An empirical investigation of social bonds and juvenile delinquency in Hong Kong. Child \& Youth Care Forum, 41(4), 371-386. doi:10.1007/s10566-012-9172-z

Costa, C. R. B. S. F., \& Assis, S. G. (2006). Fatores protetivos a adolescentes em conflito com a lei no contexto socioeducativo [Protective factors for adolescents in conflict with the law within the social-educational context]. Psicologia \& Sociedade, 18(3), 74-81. doi:10.1590/S0102-71822006000300011

Estevam, I. D., Coutinho, M. P. L., \& Araújo, L. F. (2009). Os desafios da prática socioeducativa de privação de liberdade em adolescentes em conflito com a lei: Ressocialização ou exclusão social? [Challenges of the social educative practice of freedom restrictions on adolescents in conflict with the law: Would it be ressocialization or social exclusion?] Psico, 40(1), 64-72.

Feijó, M. C., \& Assis, S. G. (2004). O contexto de exclusão social e de vulnerabilidades de jovens infratores e de suas famílias [The context of social exclusion and young offenders vulnerabilities and their families]. Estudos de Psicologia (Natal), 9(1), 157-166. doi:10.1590/S1413294X2004000100017

Ford, J. A., \& Schroeder, R. D. (2011). Higher education and criminal offending over the life course. Sociological Spectrum, 31(1), 32-58. doi:10.1080/02732173.2011.52 5695

Freitas, L. C. (2007). Eliminação adiada: O ocaso das classes populares no interior da escola e a ocultação da (má) qualidade do ensino [Deferred elimination: The twilight of the popular classes within schools and the concealment of the (bad) quality of teaching]. Educação 
\& Sociedade, 28(100), 965-987. doi:10.1590/S010173302007000300016

Hirschfield, P. (2009). Another way out: The impact of juvenile arrests on high school dropout. Sociology of Education, 82(4), 368-393. doi:10.1177/003804070908200404

Janosz, M., \& Le Blanc, M. (1999). Abandono escolar na adolescência: Factores comuns e trajectórias múltiplas [Dropout in adolescence: Common factors and multipath]. Revista Portuguesa de Pedagogia, 34(1, 2, 3), 341-403.

Jost, M. C. (2010). Fenomenologia das motivações do adolescente em conflito com a lei [Phenomenology of adolescent's motivations in conflict with the law]. Psicologia: Teoria e Pesquisa, 26(1), 99-108. doi:10.1590/ S0102-37722010000100012

Kobayashi, M. C. M., \& Zane, V. C. (2010). Adolescente em conflito com a lei e sua noção de regras no jogo de futsal [Adolescent in conflict with the law and his notion of rules in the court soccer game]. Revista Brasileira de Educação Física e Esporte, 24(2), 195-204. doi:10.1590/ S1807-55092010000200004

LeBlanc, M. (1994). Family, school, delinquency and criminality, the predictive power of an elaborated social control theory for males. Criminal Behavior and Mental Health, 4, 101-117.

Le Blanc, M. (1997). La régulation sociale et personnelle de la conduite marginale [Social and personal control of delinquent behavior]. In Manuel sur des mesures de l'adaptation sociale et personnelle pour les adolescents québécois [Manual on measures of social and personal adjustment for Quebec adolescents] (pp. 3-22). Montréal, Canada: Le Presses de l'Université de Montréal.

Le Blanc, M. (2001a). Review of clinical assessment strategies and instruments for adolescent offenders. In R. R. Corrado, R. H. Roesch, S. D. Hart, \& J. K. Gierowski (Eds.), Multi-problem violent youth: A foundation for comparative research on needs, interventions, and outcomes (pp. 171-190). Amsterdam, The Netherlands: IOS Press.

Le Blanc, M. (2001b). MASPAQ: Mesures de l'adaptation sociale et personnelle pour les adolescents québécois: Manuel et guide d'utilisation: Version 2.0 [MASPAQ: Measures of social and personal adjustment for Quebec adolescents: Manual and user guide: Version 2.0] (4th ed.). Montréal, Canada: Université de Montréal/École de Psycho-Education.

Le Blanc, M., Ouimet, M., \& Szabo, D. (2003). Traité de criminologie empirique [Empirical criminology treaty] (3th ed.). Montréal, Canada: Le Presses de l'Université de Montréal.

Lei No. 12.594, de 18 de janeiro de 2012. (2012, 20 de janeiro). Institui o Sistema Nacional de Atendimento Socioeducativo (Sinase), regulamenta a execução das medidas socioeducativas destinadas a adolescente que pratique ato infracional [Establishing the National System of Socio-Educational Services (Sinase) regulates the enforcement of social and educational measures to adolescents who practices infraction]. Retrieved from http://www.planalto.gov.br/ccivil_03/_ato20112014/2012/lei/112594.htm

Liljeberg, J. F., Eklund, J. M., Fritz, M. V., \& Klinteberg, B. (2011). Poor school bonding and delinquency over time: Bidirectional effects and sex differences. Journal of Adolescence, 34(1), 1-9. doi:10.1016/j. adolescence.2010.03.008

Lima, L. C. A. (2011). Da universalização do ensino fundamental ao desafio de democratizar o ensino médio em 2016: O que evidenciam as estatísticas? [From the elementary school universalization to the secondary school democratization in 2016: What do statistics show?] Revista Brasileira de Estudos Pedagógicos, 92(231), 268284.

Lima, L. C. A., \& Gomes, C. A. (2013). Ensino médio para todos: Oportunidades e desafios [Secondary education for all: Opportunities and challenges]. Revista Brasileira de Estudos Pedagógicos, 94(238), 745-769. doi:10.1590/ S2176-66812013000300006

Maddox, S. J., \& Prinz, R. J. (2003). School bonding in children and adolescents: Conceptualization, assessment, and associated variables. Clinical Child and Family Psychology Review, 6(1), 31-49. doi:10.1023/A:1022214022478

Miller, K. E., Melnick, M. J., Barnes, G. M., Sabo, D., \& Farrell, M. P. (2007). Athletic involvement and adolescent delinquency. Journal of Youth and Adolescence, 36(5), 711-723. doi:10.1007/s10964-006-9123-9

Moshman, D. (2005). Adolescent psychological development: Rationality, morality and identity. Mahwah, NJ: Lawrence Erlbaum.

Neri, M. (Ed.). (2009). Motivos da evasão escolar: O tempo de permanência na escola e as motivações dos semescola [Reasons for truancy: The time spent in school and the motivations of no-school]. Rio de Janeiro, RJ: FGV/IBRE/CPS. Retrieved from http://www.cps.fgv.br/ ibrecps/TPE/TPE_Motiva $\% \mathrm{C} 3 \% \mathrm{~A} 7 \% \mathrm{C} 3 \% \mathrm{~B} 5$ esEvas $\% \mathrm{C}$ 3\%A3oEscolar_Sumario.pdf

Oliveira, C. A. (2002). A fuga da escola como preditor do fenômeno delinquencial [The escape from school as a cause of the delinquency phenomenon]. Aletheia, 15, $27-$ 36.

Pasquali, L. (1998). Princípios de elaboração de escalas psicológicas [Principles of elaboration of psychological scales]. Revista de Psiquiatria Clínica, 25(5), 206-213.

Sartório, A. T., \& Rosa, E. M. (2010). Novos paradigmas e velhos discursos: Analisando processos de adolescentes em conflito com a lei [New paradigms and old discourses: Analyzing proceedings of adolescents in conflict with the law]. Serviço Social e Sociedade, 103, 554-575. doi:10.1590/S0101-66282010000300008

R Development Core Team. (2011). R 2.14 [computer software]. Vienna, Austria: R Foundation for Statistical Computing.

Toledo, G. W., \& Bazon, M. R. (2005). A delinquência juvenil no estado de São Paulo: Estudo de sua evolução entre 1950 e 2002 [The juvenile deliquency in the State of 
São Paulo: Study its evolution between 1950 and 2002]. In Z. M. M. Biasoli-Alves, I. M. F. Mattiusso Alves, L. H. R. Carvalhaes, \& P. Duarte. (Eds.), Programa de pósgraduação em psicologia: Livro de artigos [Graduate program in psychology: Book of articles] (Vol. II, pp. 299-309). Ribeirão Preto, SP: Legis Summa.

Zappe, J. G., \& Ramos, N. V. (2010). Perfil de adolescentes privados de liberdade em Santa Maria/RS [Profile of adolescents deprived of freedom in Santa Maria/RS]. Psicologia \& Sociedade, 22(2), 365-373. doi:10.1590/ S0102-71822010000200017

Jorge Luiz da Silva holds a master's degree in Psychology from the Faculdade de Filosofia, Ciências e Letras de Ribeirão Preto at the Universidade de São Paulo.

Ana Raquel Lucato Cianflone is a Professor of the Faculdade de Filosofia, Ciências e Letras de Ribeirão Preto at the Universidade de São Paulo.

Marina Rezende Bazon is a Professor of the Faculdade de Filosofia, Ciências e Letras de Ribeirão Preto at the Universidade de São Paulo.

Received: Aug. 1, 2014

1st Revision: Feb. 13, 2015

2nd Revision: Apr. 13, 2015

Approved: Apr. 23, 2015

How to cite this article:

Silva, J. L., Cianflone, A. R. L., \& Bazon, M. R. (2015). School bonding of adolescents offenders. Paidéia (Ribeirão Preto), 26(63), 91-100. doi:10.1590/1982-43272663201611 